\title{
The Impact of Government Intervention on Municipal Bond Liquidity Premium: Evidence from China
}

\author{
Xiao-Wan Jiang \\ Correspondence: Xiao-Wan Jiang, China Academy of Public Finance and Public Policy, Central University of Finance \\ and Economics, South College Road 39\#, Haidian District, Beijing, China.
}

\author{
Received: April 1, $2019 \quad$ Accepted: April 19, $2019 \quad$ Available online: April 21, 2019 \\ doi:10.11114/aef.v6i3.4217 URL: https://doi.org/10.11114/aef.v6i3.4217
}

\begin{abstract}
Government intervention is an important factor which restricts the development of municipal bond market in China. Based on the revenue bond innovation pilot policy implemented by the Ministry of Finance in 2017, this paper uses municipal bond trading data of Chinese inter-bank bond market from May 2017 to June 2018 and the two-stage least squares method to study the impact of government intervention on the liquidity premium of municipal bonds. The results of the empirical research show: (1) The liquidity risk of municipal bonds is a factor that affects the yield spread, and the marginal impact of liquidity risk on the yield spread is about 4.6 basis points. (2) After the implementation of the revenue bond innovation pilot policy, the reduction of local government intervention significantly reduced the liquidity premium level of municipal bonds. Based on the above conclusions, we propose policy recommendations for the development of the municipal bond market in the short and long term.
\end{abstract}

Keywords: government intervention, municipal bond, liquidity premium.

\section{Introduction}

Chinese local governments have been allowed to issue municipal bonds directly since 2015. After that, government intervention occurred in municipal bond market and led to a distortion of bond price, as well as poor liquidity in secondary market. It is obvious that the local governments have incentives to intervene in municipal bond pricing in primary market. A lower coupon rate will significantly reduce financing costs and help local governments to achieve more financial resources. The deep reason behind the incentives is that in the context of fiscal decentralization, problems such as distorted incentives for local officials, imperfect taxation system, aiming of macro-control and fiscal policy make the problem of local government debt in China more complicated (Gong et al., 2011). The logic of government intervention affecting the liquidity premium of municipal bonds is that in order to save financing costs, local governments use non-market-based means to reduce the interest rates, resulting in the issuance price of municipal bonds in the primary market being higher than the secondary market valuation. The reluctance of underwriters to take losses from selling municipal bonds at low prices in the secondary market leads to a further deterioration in municipal bond liquidity, which in turn pushes up the liquidity premium of municipal bonds.

In order to solve these problems and to develop municipal bond market of China, Chinese Ministry of Finance released a pilot policy on municipal bond innovation in 2017. This pilot policy asks local governments to specify the projects category of the revenue bond and municipal or county governments who use the fund and pay the principal and interest. If the municipal bond issuers decide to issue innovative revenue bonds, they could not manipulate the issuance price by packing different projects together, which may have different levels of risk. As a result, the pilot policy has mitigated government intervention and improved the transparency and information accuracy of revenue bond. It has been proved that the improvement of bond transparency has a positive effect on liquidity (Goldstein et al., 2007). In this paper, we use the pilot policy on municipal bond innovation as a quasi-natural experiment, to explore whether less government intervention could decrease the liquidity premium and efficiency loss.

\section{Literature Review}

\subsection{Fiscal Decentralization and Incentive of Government Intervention}

From the 1950s to the 1970s, major breakthroughs were made in the study of fiscal decentralization theory. A large number of far-reaching research results emerged. These research results demonstrate the necessity and rationality of local governments to provide public goods, clarify the principle of dividing the functions and powers between the 
central and local governments, and emphasize the importance of local governments in improving the efficiency of public goods supply and the welfare of residents (Tiebout, 1956; Stigler, 1957; Musgrave, 1959; Oates, 1972). Taxation and debt constitute the main source of fiscal revenue for local governments under the fiscal decentralization system. Given the differences in regional natural condition, economic development, per capita income, and the cost of public goods supply, if local governments' fiscal revenue is entirely obtained through taxation and capital market financing, horizontal fiscal imbalances will be induced among regions. Central government could use intergovernmental transfer payments to solve this problem (Bird \& Smart, 2002). However, the central government's fiscal equalization policy will lead local governments to over-spend or over-borrow in order to obtain more central government transfer payments. It could lead to vertical fiscal imbalances between central and local governments, which in turn could lead to problems of public pools and weak budgetary constraints.

In China, fiscal decentralization is carried out under a "championship" promotion mechanism for local government officials. Government competition based on performance assessment has exacerbated the distortion of fiscal decentralization in the local government expenditure structure (Li \& Zhou, 2005). The distortion in incentives for local officials makes local government debt issuance in China further complicated (Gong et al., 2011). In addition, dual roles of economic participants and political participants, promotion incentives for local government officials, and soft budget constraints in the banking industry create incentives for local governments to over-borrow.

After local governments could issue municipal bonds in 2015, they still have the incentive to intervene to secure more financial resources by lowering bond issuance rates. Wang (2018) believes that non-market behavior related to government intervention is a factor that induces the phenomenon that the local government bond issuance rate is lower than the issuance rate of treasury bond of the same period. On the one hand, the central government's implicit guarantee makes the issuing rate of local government bonds unable to effectively reflect the local government's financial situation and the economic development of the region. On the other hand, local governments have the right to allocate financial resources in the region and can influence the decision of the underwriters by intervening in the credit market.

\subsection{Impact of Government Intervention on Capital Markets}

The influence of government intervention on the capital market in China is not a new phenomenon. Before being allowed to issue municipal bonds, local governments affected the allocation efficiency of capital markets through intervening in the financing process of state-owned enterprises. Chen et al. (2011) prove that government intervention in SOEs' investment behavior leads to investment inefficiency in China.

First, government intervention directly led to the increase of non-performing loans in commercial banks. Tan et al. (2012) use the non-performing assets data of a state-owned commercial bank from 1988 to 2005 in China, and find that government intervention is the main reason for banks to generate non-performing loans. Tan et al. (2012) point out that the promotion incentives of government officials, fiscal decentralization, and the reform of the divided financial system of local government induce government intervention. Property rights of enterprise, the degree of regional marketization, and the regional legal environment will significantly affect local government intervention. In the non-state-owned enterprises and the higher degree of marketization, the non-performing loans of commercial banks are less, and the loan term is shorter and the guarantee coefficient is higher. Regional legal supervision effectively inhibits the generation of non-performing loans of commercial banks.

Second, government intervention affects the term structure of enterprise financing by means of implicit government guarantee. Sun et al. (2005) use the empirical data of listed companies in China from 1999 to 2003 as a research sample, and the research results show that under the institutional environment where the judicial system is not yet perfect, the "government relations" of enterprises reflect the possibility of the government providing implicit guarantees. In regions with a high degree of marketization, the government has less intervention in the capital market, enterprises need to bear higher financing costs in an environment where the judicial system is weak, and the long-term debt of enterprises accounts for a relatively low proportion of total debt. If government intervenes more, the implicit guarantee of the government reduces the financing cost of the enterprise, and the long-term debt of the enterprise accounts for a higher proportion of the total debt. Therefore, when the long-term debt contract could not be effectively guaranteed by the judicial system, "government relations" become an important alternative mechanism. Similarly, Yu and Pan (2008) believe that local governments interfere with commercial bank credit decisions in order to provide credit support to state-owned enterprises. Such interference in capital markets is inefficient. The rule of law and the development of capital market could correct the distortion in the allocation of resources caused by such government intervention.

Third, government intervention has exacerbated conflicts among shareholders within the enterprise and between controlling shareholders and bank creditors. Gao et al. (2006) find that government intervention has made the principal-agent problem more prominent. Under those circumstances, the controlling shareholders may take the assets and profits of the company as their own through legal or even illegal means, at the expense of minority shareholders and bank creditors. The more government intervention, the more funds the controlling shareholders will encroach. As a 
result, government intervention indirectly leads to the loss of social welfare.

\subsection{Liquidity Premium in Municipal Bond Market}

Wang et al. (2008) quantitatively estimated the liquidity premium of U.S. municipal bonds. They follow the method used by Pastor and Stambaugh (2003), which is used to study the liquidity premium of the stock market. They use the transaction data of the United States Municipal Bond Rulemaking Committee (MSRB) to confirm the impact of liquidity, default risk, and personal tax rate factors on municipal bond yield spread. Especially after adding liquidity factors, the interpretation of the municipal bond pricing model is greatly improved. Schwert (2017) uses three direct and complementary methods to decompose the difference between the yield of municipal bonds and treasury bonds into liquidity factors and default risk factors, and measures the impact of liquidity factors on yields. The empirical results show that liquidity has a significant explanatory power on the tax-adjusted yield spread. After adding liquidity factors, the R square of the regression increases from $17 \%$ to $29 \%$.

However, little literature studies the impact of government intervention on the liquidity premium of municipal bonds in China. Existing researches on the Chinese municipal bond market mainly focus on three areas. First, some researches focus on the analysis of the factors that affect the cost of issuing municipal bonds, such as the studies of Tong and Huang (2014) and Liu et al. (2017). Second, some focus on the impact of government guarantees on the cost of financing local government debt, risk premiums and the growth of local debt, such as studies by Han and Hu (2015), Wang and Chen (2015), and Ma and Ma (2018). Third, some focus on the impact of budget constraints or market constraints on the risk premium of municipal bonds, such as Wang et al. (2016), Zhu and Wang (2018). For the first time, this paper takes the pilot policy of revenue bond innovation in China as a quasi-natural experiment which reduces the degree of government intervention, and analyzes the impact of government intervention on the liquidity premium of municipal bonds from an empirical perspective.

\section{Data and Empirical Methodology}

\subsection{Hypothesis of Empirical Study}

The impact of government intervention on the liquidity premium of municipal bonds stems from the distortion of price in the primary market. If local governments bring down the coupon rate in a non-market-based manner, there would be a certain price spread between the primary market issuance and the secondary market valuation. Underwriters have to bear part of the losses if they sell high-priced municipal bonds in the secondary market. Therefore, underwriters are more likely to hold municipal bonds to maturity. Government intervention makes it more difficult for traders in the inter-bank bond market to find their counterparties through inquiring. The increased transaction costs will increase the yield spread of municipal bond in the form of liquidity premiums.

Since the revenue bond innovation pilot policy has reduced the degree of local government intervention in project selection, the information accuracy and transparency of municipal bond market is improved. The bond liquidity premium is likely to decline by bringing the issuance price closer to the valuation of municipal bonds in the secondary market. The hypothesis of empirical study is as follows.

H0: The liquidity risk is one of the factors that affect municipal bonds yield spread and less government intervention will reduce liquidity premium levels.

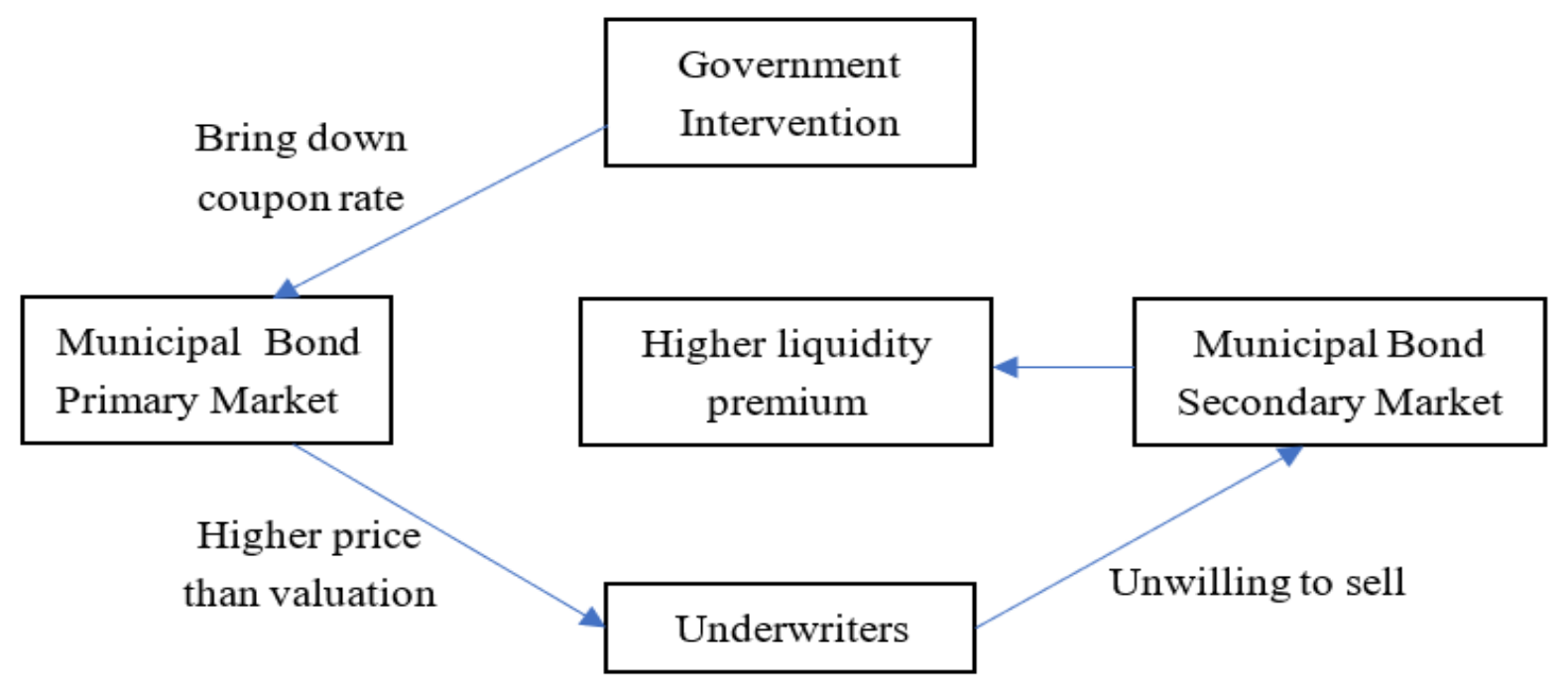

Figure 1. How Government Intervention Affects Municipal Bonds Liquidity Premium 


\subsection{Data}

This paper takes the daily trading settlement data of municipal bonds in the inter-bank bond market as samples. The range of data is from May 2017 to June 2018, which does not include the targeted replacement bonds. All bonds were issued and listed after the Ministry of Finance issued the pilot policy of revenue bonds innovation. The resources of data are as follows: Resset database, China Bond Information Network, Wind database and the statistical database of the China Economic Network. The data source of liquidity risk variable and control variables of bond characteristics is the Resset database. The data source of inter-bank borrowing rates, government debt ratios and instrumental variables is the Wind database. The data source of per capita GDP and its growth rate, fiscal income and expenditure variables is the statistical database of the China Economic Network.

\subsection{Empirical Model}

We use the two-stage least squares method to solve the endogeny problem between liquidity and yield spread.

$$
\begin{gathered}
\text { Stage 1: } \text { liquidityris }_{i, t}=\beta_{0}+\beta_{1} \text { bidgap }_{i}+\beta_{2} \text { entitytradevol }_{t}+X \beta+\varepsilon_{i, t} \\
\text { Stage 2: } \text { yieldspread }_{i, t}=\gamma_{0}+\gamma_{1} \text { liquidityrisk }_{i, t}+Z \gamma+\epsilon_{i, t}
\end{gathered}
$$

At the first stage, liquidityrisk $_{i, t}$ measures the liquidity risk of municipal bonds, calculated by the following formula.

$$
\text { Liquidityrisk }_{i, t}=\frac{\text { Spread }_{i, t}}{\text { Avgsetsum }_{i, t}}=\frac{100\left(P_{i, t}^{\max }-P_{i, t}^{\min }\right) / P_{i, t}^{\text {avg }}}{\text { Totalsetsums }_{i, t} / \text { Setdeals }_{i, t}}
$$

This method of measurement stems from an elastic method summarized by Harris (1990). Spread $_{i, t}$ is a variable that represents price fluctuations. It defines price fluctuations as dividing the price spread by the average transaction price. $P_{i, t}^{\max }$ and $P_{i, t}^{\min }$ indicate the highest price and lowest price. $P_{i, t}^{a v g}$ indicates the average price of the day. Avgsetsum $_{i, t}$ is the average trading volume, obtained by dividing the daily trading volume by the number of deals.

In order to eliminate the interference of endogenous problem between liquidity risk and yield spread, this paper selects the difference between coupon rate and the lower limit of the bid rate and the trading volume of the Shanghai Stock Exchange on the day of trading (in billions of shares) as the instrumental variables of liquidity risk. First, the bid rate range is determined by the local government in consultation with the lead underwriter before issuance. The closer the final bid rate is to the lower limit of the bid rate, the more likely local governments will intervene in the pricing of bond issuance, and the worse the liquidity of municipal bonds will be. Secondly, the stock turnover of Shanghai Stock Exchange reflects the overall liquidity of the stock market, which will affect the asset allocation of institutional investors and the trading behavior in the inter-bank market, thus affecting the liquidity of municipal bonds. Finally, the above two instrumental variables will not have a direct impact on the risk and yield of municipal bonds. From the perspective of qualitative research, it can be considered that the instrumental variables meet the exogenous requirements.

At the second stage, yieldspread int $_{\text {is }}$ is the yield spread between municipal bonds and treasury bonds with the same maturity.

$X$ and $Z$ are the control variables, including bond characteristics, fiscal and economic condition variables, such as coupon rate, issuance spread, maturity, existing year, issuing scale, per capita GDP, GDP growth rate, fiscal balance index and its square, debt ratio.

\section{Empirical Analysis}

\subsection{Regression Results}

The regression results, estimated by the two-stage least squares method, are shown in Table 4. Column (1) uses the full sample for empirical model estimation. Column (2) uses the sample of non-specific categories of revenue bonds. Column (3) uses the sample of specific categories of revenue bonds in the pilot policy. The above regression estimates are all based on robust standard errors.

Table 1. 2SLS estimation results

\begin{tabular}{llll}
\hline & $(1)$ & $(2)$ & $(3)$ \\
Variables & All & Non-specific categories & specific categories \\
\hline liquidity risk & $0.046^{* *}$ & $0.048^{* * * *}$ & -0.036 \\
& $(0.022)$ & $(0.007)$ & $(0.045)$ \\
control variables & YES & YES & YES \\
Constant & $0.879^{* * *}$ & $0.568^{* * *}$ & -1.209 \\
& $(0.249)$ & $(0.138)$ & $(1.701)$ \\
Observations & 2,260 & 1,748 & 512 \\
\hline
\end{tabular}

Robust standard errors in parentheses. ${ }^{* *},{ }^{* *}$, and $*$ denote $1 \%, 5 \%$ and $10 \%$ significance levels respectively. 
The regression results in column (1) show that the regression coefficient of municipal bond liquidity risk to the yield spread is 0.046 , and it is significant at the level of 5\%. In column (2), using the sample of non-specific categories, the regression results show that the marginal impact of liquidity risk on the yield spread is 4.8 basis points, and it is significant at the $1 \%$ level, which is very close to the coefficient of the entire sample. In column (3), using the sample of specific categories, the impact of liquidity risk on the yield spread is negative and not significant. The above regression results show that liquidity risk is an important factor that affects yield spread of municipal bonds. The reduction of government intervention has significantly reduced the liquidity premium level of municipal bonds, confirming the research hypothesis.

\subsection{Tests of Instrumental Variables}

\subsubsection{Necessity of Instrumental Variables}

In order to verify whether there is an endogenous problem between the yield spread and the elastic measure of liquidity risk, this paper makes a robust Durbin-Wu-Hausman Test. Table 2 shows the results of the endogenous test. The results show that the $\mathrm{P}$ value is 0.0000 , which strongly rejects the hypothesis that all explanatory variables are exogenous.

Table 2. Durbin-Wu-Hausman Test

Tests of endogeneity

H0: variables are exogenous

\begin{tabular}{llllllll}
\hline Robust & score & chi2(1) & $=$ & 52.06 & $(\mathrm{p}$ & $=$ & $0.0000)$ \\
Robust & regression & $\mathrm{F}(1,2251)$ & $=$ & 54.71 & $(\mathrm{p}$ & $=$ & $0.0000)$ \\
\hline
\end{tabular}

4.2.2 Exogeneity of Instrumental Variables

In order to check the exogeneity of instrumental variables, this paper adopts the Overidentify Test. Table 3 shows the result. The $\mathrm{P}$ value is 0.4224 . The hypothesis of the overidentify test is that all tool variables are exogenous. Therefore, the hypothesis could not be rejected at a significant level of $1 \%$, which confirms the exogeneity of instrumental variables.

Table 3. Overidentify Test

Test of overidentifying restrictions

$\begin{array}{llll}\text { Score } \operatorname{chi} 2(1)=0.644 & (\mathrm{p} & = & 0.4224)\end{array}$

4.2.3 Explanatory Power of Instrumental Variables

In order to check the explanatory power of instrumental variables, the correlation test of the first stage regression is carried out. The results are shown in Table 4. The results show that although the value of Shea's Partial $\mathrm{R}^{2}$ is only 0.0517 , the value of the F statistic is 18.5 , which could strongly reject the original hypothesis that the coefficients of the instrumental variables are 0 at the $1 \%$ level. In addition, the results in Table 4 also show that the minimum eigenvalue statistic of the regression results in this paper is 61.4. The benchmark value of 2SLS Size of Nominal 5\% Wald Test at the $10 \%$ statistical level is 19.93 , so the original hypothesis that weak instrumental variables exist is strongly rejected.

Table 4. First-stage regression summary statistics

\begin{tabular}{|c|c|c|c|c|c|c|c|}
\hline \multicolumn{8}{|c|}{ First-stage regression summary statistics } \\
\hline $\begin{array}{l}\text { Variable } \\
\text { liquidity }\end{array}$ & $\begin{array}{l}\text { R-sq. } \\
0.0613\end{array}$ & $\begin{array}{l}\text { Adjusted R-sq. } \\
0.0584\end{array}$ & $\begin{array}{l}\text { Partial R-sq. } \\
0.0517\end{array}$ & \multicolumn{2}{|c|}{$\begin{array}{l}\text { Robust F }(2,2246) \\
18.5064\end{array}$} & \multicolumn{2}{|c|}{$\begin{array}{l}\text { Prob }>F \\
0.0000\end{array}$} \\
\hline Shea's & partial & R-squared & & & & & \\
\hline $\begin{array}{l}\text { Variable } \\
\text { liquidity }\end{array}$ & \multicolumn{2}{|c|}{$\begin{array}{l}\text { Shea's Partial R-sq. } \\
0.0517\end{array}$} & \multicolumn{3}{|c|}{$\begin{array}{c}\text { Shea's Adj. Partial R-sq. } \\
0.0492\end{array}$} & & \\
\hline Minimum & \multicolumn{2}{|c|}{$\begin{array}{l}\text { Critical Values } \\
\text { Ho: Instruments are weak }\end{array}$} & \multicolumn{2}{|c|}{$\begin{array}{l}\text { \# of endogenous regressors: } \\
\text { \# of excluded instruments: }\end{array}$} & $2^{1}$ & & \\
\hline \multicolumn{3}{|c|}{ 2SLS relative bias } & $\begin{array}{l}5 \% \\
\text { (not available }\end{array}$ & $10 \%$ & & $20 \%$ & $30 \%$ \\
\hline \multicolumn{3}{|c|}{$\begin{array}{l}\text { 2SLS Size of nominal } 5 \% \text { Wald test } \\
\text { LIML Size of nominal } 5 \% \text { Wald test }\end{array}$} & $\begin{array}{l}10 \% \\
19.93 \\
8.680\end{array}$ & $\begin{array}{l}15 \% \\
11.59 \\
5.330\end{array}$ & & $\begin{array}{l}20 \% \\
8.750 \\
4.420\end{array}$ & $\begin{array}{l}25 \% \\
7.250 \\
3.920\end{array}$ \\
\hline
\end{tabular}

What's more, this paper uses the limited information maximum likelihood (LIML) method to test the explanatory power of instrumental variables from another perspective. The LIML method is less sensitive to weak instrumental variables and can verify the interpretation ability of instrumental variables. The regression results of the LIML method are shown 
in Table 5. The results are very similar to that of Table 1. Therefore, it can be considered that there is no weak instrumental variables problem.

\subsection{Robustness Tests}

\subsubsection{GMM Method}

To test the robustness of the 2SLS regression results, this paper uses generalized method of moments (GMM). The results are shown in Tables 6 . The results are very similar to that of Table 1 .

Table 5. LIML estimation results

\begin{tabular}{llll}
\hline & $(1)$ & $(2)$ & $(3)$ \\
Variables & All & Non-specific categories & specific categories \\
\hline liquidity risk & $0.048^{* *}$ & $0.049 * * *$ & -0.067 \\
& $(0.024)$ & $(0.008)$ & $(0.154)$ \\
control variables & YES & YES & YES \\
Constant & $0.914 * * *$ & $0.588 * * *$ & -2.251 \\
& $(0.271)$ & $(0.143)$ & $(5.502)$ \\
Observations & 2,260 & 1,748 & 512 \\
\hline
\end{tabular}

Table 6. GMM estimation results

\begin{tabular}{llll}
\hline & $(1)$ & $(2)$ & $(3)$ \\
Variables & All & Non-specific categories & specific categories \\
\hline liquidity risk & $0.045^{* *}$ & $0.048^{* * *}$ & -0.010 \\
& $(0.021)$ & $(0.007)$ & $(0.021)$ \\
control variables & YES & YES & YES \\
Constant & $0.932^{* * *}$ & $0.554 * * *$ & -0.126 \\
& $(0.275)$ & $(0.136)$ & $(0.733)$ \\
Observations & 2,260 & 1,748 & 512 \\
\hline
\end{tabular}

\subsubsection{Alternative Measurement of Liquidity Risk}

The alternative proxy variable for measuring liquidity risk is calculated by the following formula.

$$
\text { liquidityrisk }_{i, t}=\frac{\text { Spread }_{i, t}}{\text { turnover }_{i, t} / \text { Setdeals }_{i, t}}=\frac{100\left(P_{i, t}^{\max }-P_{i, t}^{\min }\right) / P_{i, t}^{\text {avg }}}{\text { turnover }_{i, t} / \text { Setdeals }_{i, t}}
$$

The results are shown in Tables 7 . And the results are very similar to that of Table 1.

Table 7. Alternative measurement of liquidity risk

\begin{tabular}{llll}
\hline & $(1)$ & $(2)$ & $(3)$ \\
Variables & All & Non-specific categories & specific categories \\
\hline liquidity risk2 & $0.342^{* * *}$ & $0.400^{* * *}$ & $0.192^{*}$ \\
& $(0.104)$ & $(0.141)$ & $(0.104)$ \\
control variables & YES & YES & YES \\
Constant & $1.033^{* * *}$ & $0.960 * * *$ & $0.970^{* *}$ \\
& $(0.182)$ & $(0.170)$ & $(0.456)$ \\
Observations & 2,260 & 1,748 & 512 \\
\hline
\end{tabular}

\section{Conlusion}

This paper uses the pilot policy of revenue bond innovation implemented by the Ministry of Finance in China as a quasi-natural experiment, which mitigates government intervention. The empirical study is based on the trading data of revenue bonds issued between May 2017 and June 2018. The two-stage least squares method is used to test the impact of government intervention on the liquidity premium. The empirical results show that the higher the liquidity risk of municipal bonds is, the larger the yield spread will be. The marginal impact of liquidity risk on the yield spread is about 4.6 basis points. And after the implementation of the revenue bond innovation pilot policy, reducing the degree of local government intervention has reduced the marginal impact of liquidity risk on the yield spread. The robustness tests are carried out by using GMM method and new liquidity risk measurement method. The tests results support the robustness of the regression results.

Based on the above conclusions, this paper proposes the following two policy suggestions for further developing the municipal bond market in China. First, in the short term, the administrative department should focus on improving the 
market environment for issuance and trading, as well as increasing the level of liquidity and interest rate marketization. The main objectives are boosting investors' confidence, reducing price spread between primary and secondary market and strengthening market constraints. Second, in the long term, the administrative department should devote themselves to reforming and improving the local government governance system. The aim is to correct improper incentives for local governments and to strengthen their internal controls in debt management.

\section{References}

Bird, R. M., \& Smart, M. (2002). Intergovernmental fiscal transfers: International lessons for developing countries. World Development, 30(6), 899-912. https://doi.org/10.1016/S0305-750X(02)00016-5

Chen, S., Sun, Z., Tang, S., \& Wu, D. (2011). Government intervention and investment efficiency: evidence from china. Journal of Corporate Finance, 17(2), 259-271. https://doi.org/10.1016/j.jcorpfin.2010.08.004

Gao, L., He, S. H., \& Yi, C. L. (2006). State control, government intervention, bank loans and asset appropriation. Journal of Financial Research, (6), 90-98.

Goldstein, M. A., Hotchkiss, E., \& Sirri, E. R. (2007). Transparency and liquidity: a controlled experiment on corporate bonds. Review of Financial Studies, 20(2), 235-273. https://doi.org/10.1093/rfs/hhl020

Gong Q., Wang J., \& Jia S. (2011). A survey of research on local government debts and fiscal decentralization. Economic Research Journal, (7), 144-156.

Han, P. F., \& Hu, Y. M. (2015). Does the bond with government implicit guarantee usually have the lower capital cost? An empirical study on the bonds of the state-owned enterprises and the local financing platforms. Journal of Financial Research, (3), 116-130.

Harris, M. (1990). Liquidity, trading rules, and electronic trading system[M]. Monogragh Series of Finance and Economics. NYU Salomon Center.

Li, H., \& Zhou, L. A. (2005). Political turnover and economic performance: The incentive role of personnel control in china. Journal of Public Economics, 89(9-10), 1743-1762. https://doi.org/10.1016/j.jpubeco.2004.06.009

Liu, T. B., Wang, T., \& Xu, X. T. (2017). Pricing mechanism of subnational government bond in China: from the perspective of the influencing factors of issuance rates. Research on Financial and Economic Issues, (12), 76-82.

Ma, W. T., \& Ma, C. Y. (2018). Introduction of government guarantees, constraints of maintaining stable growth and the expansion trap of local government debt. Economic Research Journal, (5), 72-87.

Musgrave, R. A. (1959). The theory of public finance: A study in public economy. New York, London and Toronto: McGraw-Hill Book Company.

Oates W. E. (1972). Fiscal federalism. New York: Harcourt Brace Jovanovich.

Pastor, L., \& Stambaugh, R. F. (2003). Liquidity risk and expected stock returns. Journal of Political Economy, 111(3), 642-685. https://doi.org/10.1086/374184

Schwert, M. (2017). Municipal bond liquidity and default risk. Journal of Finance, 72(4), 492-512. https://doi.org/10.1111/jofi.12511

Stigler, G. J. (1957). Selections from the wealth of nations. Harlan Davidson.

Sun, Z., Liu, F. W., \& Li, Z. Q. (2005). Market development, government influence and corporate debt maturity structure. Economic Research Journal, (5), 52-63.

Tan, J. S., Jian, Y. Y., \& Chen, Y. (2012). The government intervention and non-performing loans: an analysis based on the data during 1988-2005 from a state-owned bank. Management World, (7), 29-43.

Tiebout, C. M. (1956). A pure theory of local expenditures. Journal of Political Economy, 64(5), 416-424. https://doi.org/10.1086/257839

Tong, S. H., \& Huang, Z. K. (2014). An empirical analysis on the influence factor of issue rates of urban construction investment bond in China. Public Finance Research, (6), 72-74.

Wang, J., Wu, C., \& Zhang, F. X. (2008). Liquidity, default, taxes, and yields on municipal bonds. Journal of Banking and Finance, 32(6), 1133-1149. https://doi.org/10.1016/j.jbankfin.2007.09.019

Wang, L., \& Chen, S. Y. (2015). Implicit government guarantee, default risk and the determination of interest rate. Journal of Financial Research, (9), 66-81.

Wang, Y. Q., Chen, Y. H., \& Du, J. L. (2016). Soft budget constraint and the default risk of Chinese local government debts: evidence from the financial markets. Economic Research Journal, (11), 96-109. 
Wang, Z. G. (2018). Government intervention and "interest rates upside down" in the issuance of Chinese local government bonds. Management World, 34(11), 25-35.

Yu, M. G., \& Pan, H. B. (2008). Government intervention, legal enforcement, financial development and band loans to state-owned enterprises. Journal of Financial Research, (9), 1-22.

Zhu, Y., \& Wang, J. (2018). Can market discipline affect local government bonds' risk premium? Evidence from the Chengtou bond market. Journal of Financial Research, (6), 56-72.

\section{Copyrights}

Copyright for this article is retained by the author(s), with first publication rights granted to the journal.

This is an open-access article distributed under the terms and conditions of the Creative Commons Attribution license which permits unrestricted use, distribution, and reproduction in any medium, provided the original work is properly cited. 